\title{
Profitability and Consistency Analysis of Pharmacy Sector in India
}

\author{
Dr. K.S. Vataliya \\ Principal M.J College of Commerce \\ Maharaja Krishanakumarsinhji Bhavnagar University, Bhavnagar, India \\ Rajesh A. Jadav (Corresponding author) \\ M.J. College of Commerce \\ Maharaja Krishanakumarsinhji Bhavnagar University, Bhavnagar, India \\ Tel: 91-846-038-5821 E-mail: jadav2rajesh@gmail.com
}

Abhishek R. Belani

M.J. College of Commerce

Maharaja Krishanakumarsinhji Bhavnagar University, Bhavnagar, India

Tel: 91-971-245-8489 E-mail: belaniabhishek@gmail.com

Received: April 20, 2012

Accepted: May 4, 2012 Published: July 15, 2012

doi:10.5430/ijfr.v3n3p17

URL: http://dx.doi.org/10.5430/ijfr.v3n3p17

\begin{abstract}
In India, pharmacy sector is one the most promising \& growing industry. But form the point of view of profitability \& consistency these are the not as good as it is for overall industry $\&$ it differs from one company to other. Under the study we have taken the four major players working in the pharmacy sector in India \& taken the financial data of all the companies for four financial years. For the research purpose, there are various ratios which are calculated \& further taken into consideration for the different tests. In the study secondary data are used which are collected from internet. Objective of study is to analyze the performance of each company by profitability \& consistency under the study \& give them various ranks according to their performance. Thus, it is useful for the measurement of overall performance of various companies under pharmacy industry in India.
\end{abstract}

Keywords: Pharmacy sector in India, Profitability, Consistency

\section{Introduction}

The Indian pharmaceutical sector has come a long way, being almost non-existent before 1970 to a prominent provider of healthcare products, meeting almost 95 per cent of the country's pharmaceuticals needs.

The Industry today is in the front rank of India's science-based industries with wide ranging capabilities in the complex field of drug manufacture and technology. It ranks very high in the third world, in terms of technology, quality and range of medicines manufactured. From simple headache pills to sophisticated antibiotics and complex cardiac compounds, almost every type of medicine is now made indigenously.

Playing a key role in promoting and sustaining development in the vital field of medicines, Indian Pharmacy Industry boasts of quality producers and many units approved by regulatory authorities in USA and UK. International companies associated with this sector have stimulated, assisted and spearheaded this dynamic development in the past 53 years and helped to put India on the pharmaceutical map of the world. The Indian Pharmaceutical sector is highly fragmented with more than 20,000 registered units with severe price competition and government price control. It has expanded drastically in the last two decades. There are about 250 large units that control 70 per cent of the market with market leader holding nearly 7 per cent of the market share and about 8000 Small Scale Units together which form the core of the pharmaceutical industry in India (including 5 Central Public Sector Units). These units produce the complete range of pharmaceutical formulations, i.e. medicines ready for consumption by patients and about 350 bulk drugs, i.e., chemicals having therapeutic value and used for production of pharmaceutical formulations. Following the de-licensing of the 
pharmaceutical industry, industrial licensing for most of the drugs and pharmaceutical products has been done away with. Manufacturers are free to produce any drug duly approved by the Drug Control Authority. Technologically strong and totally self-reliant, the pharmaceutical industry in India has low costs of production, low R\&D costs, innovative scientific manpower, strength of national laboratories and an increasing balance of trade.

The total Indian production constitutes about 13 per cent of the world market in value terms and, 8 per cent in volume terms. The per capita consumption of drugs in India, stands at US\$3, is amongst the lowest in the world, as compared to Japan- US\$412, Germany- US\$222 and USA- US\$191.

\section{Objectives}

To measure the performance of the companies according to their profitability.

$>$ To measure the performance of the companies according to their consistency.

$>$ To give rankings to the sample companies as per their overall performance.

\section{Hypothesis and Research Methodology}

\subsection{Hypothesis 1}

H0: There is no significant difference between gross profit margin ratios of Companies.

Ha: There is a significant difference between gross profit margin ratio of Companies.

\subsection{Hypothesis 2}

H0: There is no significant difference between net profit margin ratios of Companies.

Ha: There is a significant difference between net profit margin ratio of Companies.

\subsection{Hypothesis 3}

H0: There is no significant difference between operating expenses ratio of Companies.

Ha: There is a significant difference between operating ratio of companies.

\section{Research Methodology}

\subsection{Type of Research}

Type of research used here is an Analytical Research, the researcher have used the facts already available and have analyze them to make a critical evaluation of the material.

\subsection{Sample Design}

Sampling design: The sampling used here is convenient sampling.

\subsection{Sample Size}

In the study, data collected from four companies consisting four financial years.

\subsection{Variables of Study}

Dependent variables: Profitability and Consistency. Independent variables: gross profit margin, net profit margin, operating expenses ratio.

\subsection{Method of Data Collection}

The data used to calculate the ratios are derived from balance sheet and profit and loss account of sample companies from the internet.

\subsection{Method of Analysis of Data}

Here data is preliminarily analyzed using a test called one-way ANOVA. ANOVA means analysis of variance. On the basis of ANOVA performed on each of the ratios some points are allocated to companies and on the basis of that conclusion is derived.

\section{Analysis and Interpretation}

\subsection{Gross Profit Margin Ratio}

Table (1) represents the gross profit margin of sample companies. Further ANOVA output form excel spreadsheet is represented in table (2) \& (3) from this results following interpretation drawn. 


\subsubsection{Interpretation}

The test gives F-ratio value which is greater than the critical value for given degree of freedom as per table (3). So the difference between Gross Profit Margin of sample companies is not because of sampling error or any other reason. This difference can be considered as a significant difference. So we can rank the companies for its profitability and consistency. We can allocate points to it ranging from 4-1as per the performance indicated by Average and Variance, given in the Summery section. They are shown in the table (4).

\subsection{Net Profit Margin}

Table (5) represents the net profit margin of sample companies. Further ANOVA output form excel spreadsheet is represented in table (6) \& (7) from this results following interpretation drawn.

\subsubsection{Interpretation}

The test gives F-ratio value which is greater than the critical value for given degree of freedom as per table (7). So the difference between Net Profit Margin of sample companies is not because of sampling error or any other reason. This difference can be considered as a significant difference. So we can rank the companies for its profitability and consistency. We can allocate points to it ranging from 4-1as per the performance indicated by Average and Variance, given in the Summery section. They are shown in table (8).

\subsection{Operating Expenses Ratio}

Table (9) represents the net profit margin of sample companies. Further ANOVA output form excel spreadsheet is represented in table (10) \& (11) from this results following interpretation drawn.

\subsubsection{Interpretation}

The test gives F-ratio value which is greater than the critical value for given degree of freedom as per table (11). So the difference between Operating Expenses Ratio of sample companies is not because of sampling error or any other reason. This difference can be considered as a significant difference. So we can rank the companies for its profitability and consistency. We can allocate points to it ranging from 4-1as per the performance indicated by Average and Variance, given in the Summery section. They are shown in table (12).

\section{Final Analysis}

In detailed analysis of each ratio, we have seen interpretation of the test performed on the ratio values of different companies. On the basis of that we can conclude which ratios can help ranking the companies on the basis of their performance.

The ratios which are considered for ranking are:

Gross profit margin

Net profit margin

Operating expenses ratio

On the basis of overall performance on ratios which are considered for ranking the following result and interpretation can be seen. We can decide the profitability and consistency of the companies and rank them for that.

\subsection{Profitability}

Table (13) shows points that the sample companies have got for their performance on each of the ratios.

The average of all values for each company shows the performance of the company for profitability. We can compare companies on the basis of their average values as per table (14).

The higher the average value, the higher the profitability of that company. According to this we get following result for profitability as per table (15).

\subsection{Consistency}

The table (16) shows points that the sample companies have got for their performance on each of the ratios.

The average of all values for each company shows the performance of the company for profitability. We can compare companies on the basis of their average values as per table (17).

The higher the average value, the higher the consistency of that company. According to this we get result for consistency as per table (18). 


\section{Limitations, Findings \& Conclusion}

\subsection{Limitations}

The study involves only four years of comparison. So it can only predict the profitable trend for these years, not more than that.

The value of ratios depends on the definition of ratio and can vary slightly according to its definition in case of different companies.

The study involves only major players of pharmacy sector in India, not all the companies.

\subsection{Findings}

Average of Cipla was the highest among all the companies showing the highest profitability which was followed by Dr. Reddy`s \& Sun Pharma, the lowest average Gross Profit was of Aurobindo.

The huge gap between average net profit \& gross profit in case of Sun Pharma can visible showing the big burden of operating expenses in the company. The lowest operating ratio is in SAIL showing good control of management over the cost.

From the analysis and its interpretation we can find out which ratios are more important and which are less important in this particular case.

Gross Profit Margin, Net profit margin and Operating expenses ratio are more useful in allocating points to the companies for their performance.

Return on total assets, return on net assets, return on equity and Dividend pay-out ratio are less important in this case so we can't use them for allocating points to the companies as their performance is almost similar on these criteria.

\subsection{Conclusion}

The major players of Pharmacy sector shows upwards trend in case of profitability. We can study the performance and rank the companies for its profitability; Cipla secured the first rank \& Dr.Reddy`s, Sun Pharma, Aurobindo followed by rest of companies.

We can study the performance and rank the companies for its consistancy; Aurobindo secured the first rank \& Sun Pharma, Dr. Reddy`s, Cipla followed by rest of companies.

\section{References}

C. R. Kothari. (2004). Research Methodology Methods \& Techniques. New Age International Publishers.

Dr. K. S. Vataliya. (2008). Management of Working Capital analysis planning \& control. Paradise Publishers.

http://money.rediff.com/companies/cipla-ltd/12540010/ratio

http://money.rediff.com/companies/dr-reddys-laboratories-ltd/12540015/ratio

http://money.rediff.com/companies/sun-pharmaceutical-industries-ltd/12540191/ratio

http://money.rediff.com/companies/aurobindo-pharma-ltd/12540244/ratio

I M. Pandey. (2009). Financial Management. Vikas Publishing House Pvt. Ltd.

M Y Khan \& P. K Jain. (2007). Financial Management. Tata McGraw-Hill Education.

Table 1. Gross profit margin raito of sample companies

\begin{tabular}{|l|c|c|c|c|}
\hline & Dr. Reddy's & Cipla & Sun Pharma & Aurobindo \\
\hline 2011 & 18.72 & 16.65 & 4.58 & 20.40 \\
\hline 2010 & 19.70 & 21.68 & 9.86 & 20.35 \\
\hline 2009 & 14.11 & 20.88 & 0.79 & 15.54 \\
\hline 2008 & 12.58 & 17.16 & 6.01 & 10.87 \\
\hline
\end{tabular}


Table 2. Summary output of ANOVAs results gross profit margin ratio

\begin{tabular}{|c|c|c|c|c|}
\hline Groups & Count & Sum & Average & Variance \\
\hline Dr. Reddy`s & 4 & 65.11 & 16.2775 & 12.01629 \\
\hline Cipla & 4 & 76.37 & 19.0925 & 6.530225 \\
\hline Sun Pharma & 4 & 21.24 & 5.31 & 14.05193 \\
\hline Aurobindo & 4 & 67.16 & 16.79 & 20.77153 \\
\hline
\end{tabular}

Table 3. ANOVAs results gross profit margin raito

\begin{tabular}{|c|c|c|c|c|c|c|}
\hline Source of Variation & SS & df & MS & F & P-value & F crit \\
\hline $\begin{array}{c}\text { Between } \\
\text { Groups }\end{array}$ & 455.5222 & 3 & 151.8407 & 11.38023 & 0.0008 & 3.490295 \\
\hline $\begin{array}{c}\text { Within } \\
\text { Groups }\end{array}$ & 160.11 & 12 & 13.3425 & & & \\
\hline Total & 615.6321 & 15 & & & & \\
\hline
\end{tabular}

Table 4. Ranking of companies based on gross profit margin analysis

\begin{tabular}{|c|c|c|}
\hline & Profitability & Consistency \\
\hline Dr. Reddy`s & 2 & 3 \\
\hline Cipla & 4 & 4 \\
\hline Sun Pharma & 1 & 2 \\
\hline Aurobindo & 3 & 1 \\
\hline
\end{tabular}

Table 5. Net Profit margin ratio of sample companies

\begin{tabular}{|c|c|c|c|c|}
\hline & Dr. Reddy's & Cipla & Sun Pharma & Aurobindo \\
\hline 2011 & 16.84 & 14.98 & 42.46 & 14.33 \\
\hline 2010 & 18.48 & 18.97 & 33.99 & 16.09 \\
\hline 2009 & 13.20 & 14.58 & 31.43 & 4.54 \\
\hline 2008 & 13.57 & 16.43 & 31.01 & 12.41 \\
\hline
\end{tabular}

Table 6. Summary output of ANOVAs results net profit margin ratio

\begin{tabular}{|c|c|c|c|c|}
\hline Groups & Count & Sum & Average & Variance \\
\hline Dr. Reddy`s & 4 & 62.09 & 15.5225 & 6.562958 \\
\hline Cipla & 4 & 64.96 & 16.24 & 3.944067 \\
\hline Sun Pharma & 4 & 138.89 & 34.7225 & 28.34289 \\
\hline Aurobindo & 4 & 47.37 & 11.8425 & 25.95916 \\
\hline
\end{tabular}

Table 7. ANOVAs results net profit margin raito

\begin{tabular}{|c|c|c|c|c|c|c|}
\hline Source of Variation & SS & df & MS & F & P-value & F crit \\
\hline $\begin{array}{c}\text { Between } \\
\text { Groups }\end{array}$ & 1267.132 & 3 & 422.3775 & 26.06903 & 1.529646 & 3.490295 \\
\hline $\begin{array}{c}\text { Within } \\
\text { Groups }\end{array}$ & 194.4272 & 12 & 16.20227 & & & \\
\hline Total & 1461.56 & 15 & & & & \\
\hline
\end{tabular}


Table 8 . Ranking of companies based on net profit margin analysis

\begin{tabular}{|c|c|c|}
\hline & Profitability & Consistency \\
\hline Dr. Reddy`s & 2 & 3 \\
\hline Cipla & 3 & 4 \\
\hline Sun Pharma & 4 & 1 \\
\hline Aurobindo & 1 & 2 \\
\hline
\end{tabular}

Table 9. Operating expense ratio of sample companies

\begin{tabular}{|c|c|c|c|c|}
\hline & Dr. Reddy's & Cipla & Sun Pharma & Aurobindo \\
\hline 2011 & 23.50 & 20.27 & 7.90 & 23.42 \\
\hline 2010 & 24.76 & 24.63 & 13.63 & 23.28 \\
\hline 2009 & 18.95 & 23.78 & 2.91 & 18.49 \\
\hline 2008 & 17.42 & 20.27 & 8.38 & 14.20 \\
\hline
\end{tabular}

Table 10. Summary output of ANOVAs results operating expense ratio

\begin{tabular}{|c|c|c|c|c|}
\hline Groups & Count & Sum & Average & Variance \\
\hline Dr. Reddy`s & 4 & 84.63 & 21.1575 & 12.43576 \\
\hline Cipla & 4 & 88.95 & 22.2375 & 5.281825 \\
\hline Sun Pharma & 4 & 32.82 & 8.205 & 19.1971 \\
\hline Aurobindo & 4 & 79.39 & 19.8475 & 19.42729 \\
\hline
\end{tabular}

Table 11. ANOVAs results operating expense raito

\begin{tabular}{|c|c|c|c|c|c|c|}
\hline Source of Variation & SS & df & MS & F & P-value & F crit \\
\hline $\begin{array}{c}\text { Between } \\
\text { Groups }\end{array}$ & 508.8207 & 3 & 169.6069 & 12.04125 & 0.000625 & 3.490295 \\
\hline $\begin{array}{c}\text { Within } \\
\text { Groups }\end{array}$ & 169.0259 & 12 & 14.08549 & & & \\
\hline Total & 677.8466 & 15 & & & & \\
\hline
\end{tabular}

Table 12. Ranking of companies based on operating expense ratio analysis

\begin{tabular}{|c|c|c|}
\hline & Profitability & Consistency \\
\hline Dr. Reddy`s & 3 & 3 \\
\hline Cipla & 4 & 4 \\
\hline Sun Pharma & 1 & 2 \\
\hline Aurobindo & 2 & 1 \\
\hline
\end{tabular}


Table 13. Summary of rankings based on profitability

\begin{tabular}{|c|c|c|c|c|}
\hline & Dr. Reddy's & Cipla & Sun Pharma & Aurobindo \\
\hline Gross Profit Margin & 2 & 4 & 1 & 3 \\
\hline Net Profit Margin & 2 & 3 & 4 & 1 \\
\hline Operating Expenses Ratio & 3 & 4 & 1 & 2 \\
\hline
\end{tabular}

Table 14. Summary of ranking based on profitability of sample companies

\begin{tabular}{|c|c|c|c|c|}
\hline Groups & Count & Sum & Average & Variance \\
\hline Dr. Reddy`s & 3 & 7 & 2.333333 & 0.333333 \\
\hline Cipla & 3 & 11 & 3.666667 & 0.333333 \\
\hline Sun Pharma & 3 & 6 & 2 & 3 \\
\hline Aurobindo & 3 & 6 & 2 & 1 \\
\hline
\end{tabular}

Table 15. Ranking of sample companies based on their profitability

\begin{tabular}{|c|c|}
\hline Company & Rank \\
\hline Dr. Reddy`s & 2 \\
\hline Cipla & 1 \\
\hline Sun Pharma & 3 \\
\hline Aurobindo & 4 \\
\hline
\end{tabular}

Table 16. Summary of rankings based on consistency

\begin{tabular}{|c|c|c|c|c|}
\hline & Dr. Reddy's & Cipla & Sun Pharma & Aurobindo \\
\hline Gross Profit Margin & 3 & 4 & 2 & 1 \\
\hline Net Profit Margin & 3 & 4 & 1 & 2 \\
\hline Operating Expenses Ratio & 3 & 4 & 2 & 1 \\
\hline
\end{tabular}

Table 17. Summary of ranking based on consistency of sample companies

\begin{tabular}{|c|c|c|c|c|}
\hline Groups & Count & Sum & Average & Variance \\
\hline Dr. Reddy`s & 3 & 9 & 3 & 0 \\
\hline Cipla & 3 & 12 & 4 & 0 \\
\hline Sun Pharma & 3 & 5 & 1.666667 & 0.333333 \\
\hline Aurobindo & 3 & 4 & 1.333333 & 0.333333 \\
\hline
\end{tabular}

Table 18. Ranking of sample companies based on their consistency

\begin{tabular}{|c|c|}
\hline Company & Rank \\
\hline Dr. Reddy`s & 3 \\
\hline Cipla & 4 \\
\hline Sun Pharma & 2 \\
\hline Aurobindo & 1 \\
\hline
\end{tabular}

